\title{
CÂTEVA OBSERVAȚII PRIVIND VERSIUNEA ITALIANĂ A PROVERBELOR ADUNATE DE IULIU A. ZANNE
}

\author{
Alessandro ZULIANI* \\ Some observations on the Italian translation of the proverbs \\ collected by Iuliu A. Zanne
}

\begin{abstract}
The paper aims to analyze the origin and importance of the collection Proverbele Românilor din România, Basarabia, Bucovina, Ungaria, Istria și Macedonia by Iuliu A. Zanne, monument of Romanian paremiology. The reader is also offered the translation in Italian of a series of paroemias taken from the first volume of the collection, accompanied by a commentary on the meaning of the individual proverbs and taking as well into account their main syntagmatic variants.
\end{abstract}

Keywords: proverbs, Iuliu Zanne, paremiology, traductology, idioms

\section{Introducere}

Fiind obligat dintotdeauna să se confrunte cu situaţiile complicate din viața de zi cu zi, cu problemele și grijile vieții, omul a găsit în proverbe busola care i-a permis să se orienteze în direcția cea bună, să-şi gestioneze corect propria existență și să facă alegeri inspirate din punct de vedere etic. Scurte epigrame care exprimă gânduri, adevăruri și înțelepciune fără timp istoric, proverbele au ca obiect situații dintre cele mai diferite și în general sunt exprimate în rimă, fie prin asonanță, fie prin aliterare. Totodată, proverbele se limitează uneori la constatarea unor realităţi obiective, alteori sunt metaforice și mai greu de interpretat. „Cizelate în timp, treptat, proverbele și zicătorile s-au ales de tot ce era de prisos și au ajuns să spună mult prin cuvinte puține". $\mathrm{Cu}$ cât mai mult structura lingvistică este identificată cu o construcție eliptică, cu atât mai intensă este încărcătura cognitivă, zeflemitoare, oximoronică etc. Proverbul provine dintr-un eveniment real și își propune să transmită o învățătură, devine însă trainic numai atunci când este forjat într-o structură gramaticală scurtă $\breve{a}^{2}$. Din punct de vedere ontologic, se recunoaște faptul că în proverbe apar construcțiile tradiționale ale poporului, obiectele de uz casnic, vestimentația, flora și

\footnotetext{
* Università degli Studi di Udine, Vicolo Florio, 2, 33100 Udine, ITALIA

(alessandro.zuliani@uniud.it).

${ }^{1}$ Braga 2009: 7.

${ }^{2}$ Navarro Salazar 1999: 159.
} 
fauna obișnuită, referințele la religia, tradițiile, credințele și superstițiile pe care le are etnia ${ }^{3}$.

În lucrarea de față nu ne-am propus să investigăm problematica complexă privind diferențele dintre proverbe, zicători, pilde și maxime, ci ne vom limita să remarcăm faptul că există o tradiție sapiențială cultă și o înțelepciune populară care își trage inspirația de la o viziune naivă a vieții și aderentă la realitatea concretă, dar alcătuită din materiale inculte. După cum afirmă Renzo Tosi, în cadrul acestor limite putem diferenția un nivel maxim de „rusticitate” și minim de ,autorialitate”, cum este în cazul proverbului, pentru a ajunge treptat la o expresie care este rodul unei gândiri raționale, asumate de autor, adică aparținând cuiva, cum este cazul aforismelor.

Referindu-se la conceptul de „limbaj-obiect” formulat de Roland Barthes, María Josefina Tejera Rolando remarcă cum, privind din punctul de vedere al esenței lor profunde, proverbelor le revine sarcina de a stabili legături directe cu realitatea tocmai pentru că acestea constituie dovezi, puncte ideologice de susținere, evidențiate prin caracterul lor imperativ. Ba mai mult, ,proverbele nu vorbesc despre ceea ce are cineva, ci despre ceea ce este. În această privință codurile proverbiale sunt universale, adică nu aparțin unei anumite clase sociale și, prin urmare, afectează în mod egal toate ființele umane" ${ }^{\prime 4}$. Vorbind despre cine este cineva, prin aceasta se realizează deci o generalizare convenabilă.

Prezentându-se în ordine aleatorie şi tratând subiecte eterogene, proverbele pun paremiologul în fața nevoii de a adopta o abordare tematică în faza de aranjare și ordonare a materialului colectat. $\mathrm{Nu}$ de puține ori, caracteristica acestor parimii este prezența variantelor, uneori numeroase pentru acelaşi proverb. De aceea, este destul de frecvent să găsim zicale care prezintă legături mai mult sau mai puțin marcate cu alte proverbe, dând în acest fel naștere unor secvențe de pilde cu aceeași semnificație, adică putem ordona aproximativ proverbele pe câmpuri semantice, unele dintre ele intrând în legături multiple cu două sau trei astfel de câmpuri. Uneori elementul comun este forma, alteori ideea, conceptul a ceea ce proverbul exprimă. În unele cazuri, două sau mai multe proverbe pot avea forme similare, dar semnificații diferite.

Paremiologul italian Temistocle Franceschi consideră codul de parimii ca fiind ,un instrument democratic al culturii pe care o reflectă":

Nici o generație nu ar transmite generațiilor următoare o vorbă de opinie care nu reflectă, cel puțin parțial, gândirea sa. Care, de altfel, rareori este univocă. Cum opiniile pot fi diferite, tot așa pot fi transmise "concentrate de opinie" contrastante, care pot fi utilizate în funcție de situație ${ }^{5}$.

\footnotetext{
${ }^{3}$ Carlateanu et alii 2007: 3.

${ }^{4}$ Tejera Rolando 2016: 258. Toate traducerile în limba română îi aparțin autorului.

${ }^{5}$ Franceschi 2004: XIX.
} 
Așadar, culegerile de proverbe și zicători sunt adevărate și autentice antologii de bun simț popular, rezultate în urma experiențelor fiecărui popor și fiind reprezentative pentru diferitele limbi. Este cunoscut faptul că proverbele sunt foarte vechi și au caracterizat și limbile civilizaţiilor primitive. Una dintre cărțile Vechiului Testament, atât cel aparținând canonului evreiesc, cât și cel creștin, este „Proverbele”, mai exact „Proverbele și pildele lui Solomon”. Este vorba despre cea mai tipică expresie a înțelepciunii evreiești a cărei paternitate nu i se poate atribui numai lui Solomon, contrar a ceea ce afirmă titlul textului biblic. Este prezentată ca o culegere de materiale eterogene, care include expresii populare de proveniențe diferite și care reprezintă secole de gândire erudită, fiind în fapt expresia lor maximă.

Timp de mai multe secole s-a considerat că Proverbele din Biblie reprezintă culegerea cea mai veche a acestui gen, dar datorită găsirii tăblițelor de argilă a civilizațiilor mesopotamice, am intrat în posesia mai multor colecții sumeriene de proverbe, unele dintre ele databile circa în secolul al XVIII î.e.n.. Chiar dacă aparțin unui popor cu structuri, limbă, idei, obiceiuri, economie, religie diferite de ale noastre, multe formule proverbiale dezvăluie caracteristici fundamentale similare, încât se pot stabili conexiuni în modul de cunoaştere, care pot fi recunoscute pretutindeni, în sofisticata China antică cât și în societățile primitive ${ }^{6}$.

Ideea, răspândită și împărtășită, care ar vrea ca tradiția proverbelor în culturile europene să-și întemeieze propriile origini în special pe culturile greacă și latină este doar parțial acceptabilă și necesită anumite precizări. Fără îndoială, menționarea unui proverb într-un document antic certifică existența sa și circulația în epoca respectivă, dar acest lucru nu oferă indicii de niciun fel cu privire la originea proverbului însuși. Prin urmare, eventuala atribuire autorilor clasici, greci sau latini a proverbelor citate de aceștia, nu poate face abstracție de faptul că, aproape sigur, aceste proverbe își au originea în limba poporului și, prin urmare, sunt mult mai vechi. Trebuie de asemenea amintit că există o paremiologie comparativă care studiază proverbele recurente în diferitele limbi. Dincolo de faptul că proverbele sunt universale și se transmit de-a lungul timpului de la un neam la altul, ceea ce interesează paremiologia comparativă este modul în care fiecare popor le adaptează după propriile obiceiuri, de aceea, deseori este posibil să reflecte interesante caracteristici locale, istorice și lingvistice.

\section{Lucrări precursoare}

În paremiografia românească, Iuliu A. Zanne este inițiatorul metodei de clasificare tematică. Încă din 1877, folcloristul și filologul Gheorghe Dem. Teodorescu a stabilit criterii științifice pentru culegerea, clasificarea și

\footnotetext{
${ }^{6}$ Lapucci 2006: IX.
} 
interpretarea materialului paremiologic, subliniind importanța, acolo unde există, a variantelor unice, a subdivizării pe categorii, a unui index alfabetic și a oricărui element util pentru considerații asupra eventualelor concordanțe cu proverbele din alte limbi. Zanne pune în practică indicațiile lui Teodorescu și realizează, în perioada de la sfârșitul secolului al XIX-lea și începutul secolului al XX-lea, o culegere imensă, de câteva mii de pagini, concepută după un sistem de opt categorii generale, fiecare categorie împărțită pe clase. Lucrarea care a cerut un efort deosebit și, datorită vastităţii sale, este de neegalat în cadrul cercetărilor paremiologice românești, corpus-ul de ,proverbe, zicători, povățuiri, cuvinte adevărate, asemănări, idiotisme și cimilituri” culese de Zanne a fost conceput ca o operă preliminară în vederea unui studiu paremiologic comparativ de mare amploare. În introducerea primului volum al culegerii, Zanne afirmă că intenția de a studia și de a compara parimiile poporului român cu cele străine, s-a lovit de lipsa unei colecții de proverbe românești pe care să o poată folosi. De aici a rezultat necesitatea de a culege și a documenta proverbele din spațiul românesc într-o colecție cuprinzătoare, fără precedente. Este neîndoielnic că lucrarea lui Iuliu A. Zanne reprezintă, pentru cultura românească, primul studiu paremiologic adevărat, distingându-se, în acest sens, de precedentele culegeri care rămân în contextul paremiografiei întrucât colecții simple, lipsite de comentarii referitoare la aspectele de conţinut și formă ale proverbelor. $\mathrm{Cu}$ toate acestea, Zanne pornește cu cercetările sale exact de la colecțiile predecesorilor săi: un material prețios pe care el îl integrează, clasifică, compară și analizează în baza principiilor științifice formulate de folcloristul Teodorescu, autorul studiului intitulat „Cercetări asupra proverbelor române". Dacă am dori să comparăm opera lui Zanne cu ceea ce se întâmplă în epoca aproape contemporană în alte țări europene, nu am putea evita să facem referire la italianul Giuseppe Giusti, autorul unei culegeri de proverbe toscane care, pentru a folosi cuvintele paremiologului Carlo Lapucci, a început să adune proverbele „fără a problematiza prea mult, dar cu foarte mult bun simț și nas critic" "Și lui Zanne îi lipsesc bazele filologice, însă acest lucru nu-1 împiedică să facă o comparaţie benefică între materialul înregistrat pe viu, cu ajutorul unor serii de informatori, și formele transmise de tradiţia literară, descifrând semnificația pe care expresia proverbială o are în limba românilor. Prin urmare, nu mai putem vorbi de colecții care „se prezintă ca o adunătură de materiale, lipsite de indicații de surse și de ilustrații ale valorilor paremiologice" ${ }^{\prime}$, ci de o imensă colecție în care, fiecare expresie proverbială își are un loc într-un cadru structurat, care încearcă să dea o ordine logică a ceea ce este un material dificil de gestionat

\footnotetext{
${ }^{7}$ Lapucci 2006: XXII.

${ }^{8}$ Franceschi 2004: XIX.
} 
prin natura proverbului care, pe lângă semnificația literară, ,aproape întotdeauna are și o semnificație metaforică și poate ascunde încă multe altele, prin aluzie, citare, trimitere la un fapt istoric, la o fabulă, la un comportament"". În ciuda faptului că opera lui Zanne a fost primită pozitiv de mediul academic, filologic și, în general, de lumea intelectuală românească de atunci, nu lipsesc nici criticile adresate la munca paremiologului din partea celor care pun la îndoială valoarea și importanța a ceea ce a fost realizat și a metodei științifice adoptate de savant. În cadrul Academiei Române, instituţie care acordă un spațiu amplu dezbaterii asupra volumelor lui Zanne, paremiologul se află în situația jenantă de a se confrunta cu diverse obiecții și insinuări, unele chiar nefondate, asupra modului în care a finalizat imensa culegere. În timp ce unii elogiază lucrarea, considerând-o atotcuprinzătoare a înțelepciunii populare și extrem de utilă pentru scrierile istorice, etimologice și citatele literare care însoțesc proverbele, recunoscând în Zanne calităţi, precum răbdarea și perspicacitatea, alții îl acuză pe autor de diletantism și de lipsă de originalitate: savantul s-ar fi limitat, de fapt, să reia clasificarea deja adoptată de Anton Pann, autorul operei „Povestea vorbei” din $1847^{10}$. Se ajunge inclusiv să fie pus la îndoială faptul că Zanne ar fi apelat efectiv la investigații pe teren, în ciuda afirmațiilor făcute chiar de paremiolog:

Mulțumită concursului binevoitor a multor persoane, printre care un număr însemnat de învățători din diferite părți ale țării, am putut aduna un material însemnat, atât în România cât și în Basarabia, Bucovina, în diferitele provincii ale Ungariei locuite de Români, în Istria și în Macedonia ${ }^{11}$.

Savantul consideră că proverbele și formele lor similare păstrează modul de gândire și simțire al tuturor românilor care trăiesc în România de atunci, dar și al multora care, din diferite motive istorice, trăiesc în afara granițelor țării născute din uniunea Valahiei cu Moldova. O mină de înțelepciune populară, care aparține poporului în totalitate și care, prin numeroasele teme abordate și subiectele eterogene -ca de exemplu obiceiurile și obișnuințele, organizarea vieții cotidiene- definește mentalitatea și bogăția lingvistică a unei națiuni întregi care se recunoaște în ea.

Proverbele, rod al constatărilor și reflectărilor a ceea ce se întâmplă în societățile umane, se pot schimba în timp, pentru a se alinia la schimbările lumii pe care le oglindesc și într-adevăr uneori aceste proverbe se pot și „contrazice”.

\footnotetext{
${ }^{9}$ Lapucci 2006: XXIX.

${ }^{10}$ Datcu 2004: 7.

${ }^{11}$ Zanne 2003: XLIII.
} 
Proverbele unui secol lămuresc gusturile, obiceiurile, originalitatea care îl deosebește de toate celelalte secole. Schimbându-se calitățile sau viciile unei societății, se schimbă și proverbele ei, ceea ce ne poate explica, până la un punct, pentru ce un proverb își are adeseori contrariul ${ }^{12}$.

În 1903, la opt ani de la publicarea primului volum, apare al zecelea volum al colecției. Astfel se încheie lunga activitate prin care Zanne oferă culturii române o colecție care nici până astăzi nu a fost egalată. Dar, poate, ar fi mult mai corect să vorbim despre o colecție de colecții, din moment ce, așa cum afirmă și etnologul Nicolae Constantinescu, în volumele lui Zanne găsim transcris și clasificat materialul imens provenit din sutele de documente care, la vremea respectivă, reprezintă globalitatea literaturii paremiografice românești. Colecția se deschide cu o prefață a lui Teodorescu în care folcloristul enumeră meritele lucrării lui Zanne, care, în opinia sa, reprezintă primul adevărat studiu paremiologic românesc: grija pentru variante, efortul depus pentru identificarea proverbelor autentice românești față de cele de origine străină, împărțirea pe categorii, numeroasele note bogate în informații etimologice, religioase, istorice, antropologice, etnografice și mitologice. De asemenea, dețin o importanță fundamentală, indicele alfabetice prezente la sfârșitul fiecărui volum, glosarele de cuvinte vechi pentru cititorii care întâmpină dificultății de înțelegere, indicațiile prețioase cu privire la sursele folosite, informațiile geografice precum și citatele literare și, nu în ultimul rând, bibliografia impresionantă. Prefața lui Teodorescu este urmată de o disertație a autorului, care, reamintind importanța pe care literatura de înțelepciune a avut-o încă din cea mai veche Antichitate, se oprește să definească succint proverbul; trece apoi la o expunere detaliată a literaturii paremiografice române începând cu primii ani ai secolului al XVIII-lea și cu indicațiile bibliografice referitoare la dialectele istroromâne și macedoromâne. Este foarte important spațiul dedicat de Zanne lucrărilor lui Iordache Golescu și Anton Pann. În special, paremiologul publică, pentru prima dată, întreaga colecție a lui Golescu. Numărul locuțiunilor proverbiale și al expresiilor idiomatice care compun cele zece volume, care depășesc șapte mii de pagini, se ridică, potrivit calculelor folcloristului roman Ovidiu Bârlea, la 23.440; acestora li se adaugă alte 16.350 de parimii din colecția lui Golescu, care ocupă întregul volumul VIII și prima parte a volumului IX $^{13}$.

Prin contribuțiile noastre ${ }^{14}$, am încercat să oferim, pentru prima dată, cititorilor italieni exemple de zicale și proverbe extrase din culegerea lui Zanne și, în limitele spațiului avut la dispoziție, variantele sintagmatice ale acestora care prezintă elemente deosebite de noutate față de forma

${ }^{12}$ Zanne 2003: XX.

${ }^{13}$ Constantinescu 2003: 6.

${ }^{14}$ Fanella, Zuliani 2014; Zuliani 2018. 
înregistrată ca fiind principală. Și în cazul proverbelor prezentate aici, am optat pentru traducerea celor atestate în dacoromână, omiţând variantele macedoromâne și istroromâne pentru care ar fi nevoie de o abordare lingvistică diferită. Nu am păstrat numerotarea progresivă atribuită de Zanne proverbelor unice (variante excluse), deoarece elementele pot fi identificate cu ușurință în cadrul capitolelor analizate; de asemenea, am omis semnele convenționale utilizate pentru a identifica originea proverbelor individuale, deoarece am preferat aproape întotdeauna parimiile adunate de autor și zicalele țărănești. În studiul nostru, am selectat cele mai interesante și reprezentative parimii, pe care Zanne le comentează punctual și le îmbogățește cu anecdote și povești. Ortografia pe care am adoptat-o în transcrierea proverbelor este aceea a limbii române moderne, dar am lăsat nemodificate unele forme, care astăzi nu mai sunt uzuale, pentru interesul lor lingvistic și paremiologic pe care îl prezintă. În textul original, se notează o serie de fonetisme nu neapărat dialectale (de exemplu: câne pentru câine, pĕ pentru pe , grândine pentru grindină, etc.) și anumite însușiri grafematice, cum ar fi redarea cu grafeme diferite a vocalelor central închise /í și a vocalei centrale medii /ə/ (de exemplu: vĕdênd pentru văzând, crivĕţ pentru crivăţ). În concluzie, am indicat în paranteze pătrate, când s-a putut, eventualele corespondențe italienești ale proverbelor românești.

Chiar dacă este parțial și limitat doar la o parte din imensa culegere a lui Zanne, acest studiu, ca și cele precedente, ne permite să formulăm câteva considerații generale despre munca paremiologului român. Înainte de toate, este de remarcat faptul că multe dintre aceste proverbe nu mai aparțin competenței de comunicare a vorbitorilor contemporani, care au pierdut legătura cu vechile tradiții și superstiții. Dimpotrivă, alte moduri de a spune și-au menținut actualitatea și încă fac parte din bagajul lexical și frazeologic al românilor. De asemenea, distribuția geografică a proverbelor examinate de Zanne documentează producția paremiologică a întregii arii lingvistice românești, inclusiv regiunile în care se vorbește istroromâna și macedoromâna. Acest fapt înseamnă că întreg patrimoniul idiomatic românesc este reprezentat, știindu-se că proverbele ,arată mai mult și poate mai bine decât singurele cuvinte cultura poporului și viziunea asupra vieții a comunităţilor care le folosesc"15. Mai trebuie subliniat faptul că o mare parte a proverbelor și a polirematicelor au origini foarte vechi și prezintă, la nivel lingvistic, vocabular și sintaxă adesea neobișnuite: frazeologisme care, uneori, nu pot fi comod înțelese și care, fără adnotările prețioase ale lui Zanne, nu ne-ar fi ușor să revenim la ele și la motivațiile istorice care le-au produs și să le apreciem idiomaticitatea. Î̉n această imensitate de parimii și zicale găsim expresii de o familiaritate prietenoasă, unele naive și glumețe în timp ce altele cu semnificații morale mai mult sau mai puțin profunde,

15 Trovato 2011: 84. 
enunţuri pline de ironie imaginativă și zicători la limita decenței. Toate, fără deosebire, transmit atmosfera unei lumi țărănești, și nu numai, care a supraviețuit doar parțial.

\section{Problematica transpunerii semantice a proverbelor în alte limbi}

$\mathrm{Nu}$ ne rămâne acum decât să ne ocupăm de principalele probleme legate de transpunerea proverbelor într-o altă limbă, care reprezintă, fără îndoială, una dintre cele mai complexe provocări ale traducerii. Trebuie mai întâi să ne lămurim: este oare corectă teoria potrivit căreia limba ar fi mult mai mult decât un simplu instrument de exprimare a conceptelor, ci mai degrabă un purtător de convingeri și puncte de vedere asupra societăţii și, în general, asupra lumii? Prin urmare, faptul că limba reflectă o perspectivă asupra lumii poate să aibă repercusiuni asupra traducerii ${ }^{16}$ ? Nu trebuie să uităm care este funcția esenţială a traducătorului, și anume aceea de a acționa ca mediator între un text și un cititor care nu îl poate înțelege în limba originală. Acest lucru înseamnă, în esență, că traducătorul are datoria să rămână cât mai fidel posibil textului; în consecință, traducerea este în mod inevitabil o practică subiectivă, o cale complexă și diferențiată, în fața căreia nu poate fi adoptată o singură strategie. Potrivit Audrey Wozniak, proverbul este o secvență înghețată, atestată și aparținând unei hotărâte categorii lingvistice $^{17}$. $\mathrm{O}$ anumită formă și un înțeles precis îi aparțin, iar traducerea unui proverb trebuie să țină cont de aceste elemente. Mai exact, transpunerea unei parimii într-o altă limbă ar trebui să fie, în esență, căutarea unei formule proverbiale existente. N-ar exista, deci, nici un loc pentru creație sau orice adaptare. Așadar, un proverb poate fi tradus doar printr-un proverb. Trebuie însă să ne amintim că unele proverbe definesc adevăruri care nu sunt conceptualizate în toate limbile, prin urmare conținutul semantic al proverbelor în diferite idiomuri poate fi neasemănător chiar dacă se referă la aceleași sfere conceptuale. Fiecare limbă constituie un anumit model de tot ceea ce există prin interpretarea lumii în funcție de propriul sistem semiotic care este afectat de individualitatea fiecărui cod cultural. Prin urmare, se întâmplă ca unele concepte să fie mai mult sau mai puțin exprimate, tratate într-o manieră mai mult sau mai puţin detaliată, judecate mai mult sau mai puțin pozitiv ${ }^{18}$.

Antropologul italian Eugenio Imbriani s-a concentrat asupra a ceea ce el definește drept „,forme culturale permanente de durată în contexte care nu mai sunt capabile să înțeleagă semnificația lor" din cauza transformărilor sociale și a schimbărilor de tot felul care apar în istorie ${ }^{19}$. Tradiţiile

\footnotetext{
${ }^{16}$ Osimo 2004: 32.

${ }^{17}$ Wozniak 2010: 35-36.

${ }^{18}$ Nikolaeva 2011: 203.

${ }^{19}$ Imbriani 2004. 61.
} 
populare, de exemplu, care au supraviețuit adesea grație transmiterii orale, pot pierde, de-a lungul timpului, unele dintre principiile existenței și inteligibilității lor: iată cum căutarea sensurilor autentice devine un subiect interesant. Este cazul unor proverbe sau expresii românești mai ciudate și cu un înțeles obscur, mai ales pentru un străin ca, de exemplu: „La anul cu brânză" (traducere literară în italiană: All'anno del formaggio / Quando verrà l'anno del formaggio). De ce „brânză” și, mai presus de toate, ce înseamnă în expresia românească? Ba mai mult încă, cum am putea traduce o asemenea locuţiune favorizând forma care se apropie cel mai mult de cea italiană (presupunând că există o formă italiană). În acest caz, expresia idiomatică ar putea fi tradusă numai prin recurgerea la o reformulare a frazei: Alle calende greche. În alte cazuri, este legitim să vorbim de intraductibilitate, deoarece nu poate fi găsit un echivalent în trecerea de la limba sursă la limba țintă și ar trebui să recurgem în mod necesar la o circumlocuție.

În privința dificultăților legate de traducerea unităților frazeologice și a proverbelor, s-a remarcat că acest lucru se datorează, în principal, metaforelor și muzicalității formale prezente in ele, care sunt în sine greu de tradus $^{20}$. Dar nu trebuie să uităm că elementul care distinge proverbele din punct de vedere lingvistic este, fără îndoială, conservarea, adică abilitatea de a păstra sunete, vocabular și construcții vechi aparținând unei societăți care nu mai există dar care, în parte, supraviețuiește întocmai datorită proverbelor. Cititorul sau ascultătorul care întâlnește un proverb este adesea luat prin surprindere și trebuie de multe ori să depună nu puține eforturi pentru a depăși provocările semantice pe care le prezintă parimiile, tot așa pentru traducător proverbul este adesea un obstacol dificil de depășit. Este cu siguranță utilă și înțeleaptă adoptarea unei strategii de traducere, cu alte cuvinte, găsirea celei mai bune tehnici pentru a obține o înţelegere completă a semnificației proverbelor individuale fără a trăda forma, în limitele posibilităților. Traducerea literală permite crearea unui metatext care să păstreze caracteristicile prototextului, dar adaptându-se regulilor gramaticale ale limbii țintă. Dimpotrivă, traducerea cuvânt cu cuvânt nu prevede modificarea ordinii constituenților frazei. Cunoscând gramatica și vocabularul unei limbi, ar trebui să înțelegem semnificația fiecărei expresii, dar acest mecanism mintal este insuficient în cazul proverbelor şi al expresiilor idiomatice, deoarece o serie de factori intră în joc, cum ar fi metaforele, care prezintă o serie de probleme traductologice destul de complexe.

Potrivit lui Pieragela Diadori, din momentul în care într-un prototext un proverb este identificat și interpretat în funcție de contextul în care este atestat sau utilizat, traducătorul se confruntă cu trei posibilităţi: a) există în

\footnotetext{
${ }^{20}$ Librici 2016: 461.
} 
limba țintă o expresie corespunzătoare atât în formă cât și în sens; b) nu există niciun echivalent în limba țintă; c) există o expresie similară care este utilizată totuși într-un context diferit. Iată deci care sunt posibilele abordări ale traducătorului concepute de lingvista italiană: a) proverbul poate fi tradus într-o limbă străină printr-un proverb corespunzător; b) proverbul poate fi tradus cu o propoziție care reproduce sensul proverbului, dar într-o formă diferită; c) proverbul este înlocuit de o expresie idiomatică sau de o metaforă; d) partea din textul care conține proverbul este ștearsă; e) proverbul este tradus literal ${ }^{21}$.

\section{Concluzii}

La încheierea acestei examinări, nu ne rămâne decât să reafirmăm opțiunea noastră de a traduce în mod literal parimiile colecției lui Zanne, la care am adăugat mereu o explicație a semnificației proverbului: alegerea aceasta se datorează necesităţii de a satisface atât aspectul pragmatic cât și pe cel semantic, de care toate proverbele sunt purtătoare. Considerăm că, pentru publicul italian, este important de înțeles sensul fiecărui proverb românesc și modul în care este formulat, adică forma lui lingvistică, mai puțin să găsească neapărat un omolog în limba italiană, nefiind vorba de o traducere literară, ci de o colecție în care proverbele sunt enumerate și nu apar într-un context scriitoricesc. În ultimă instanță, nu trebuie să uităm că în italiană există problema proverbelor dialectale și, prin urmare, cum ar trebui să procedăm? În cazul unei traduceri literare, cum a fost versiunea italiană a operei lui Ion Creangă de către Anna Colombo, alegerea traducătorului a căzut pe proverbe toscane, însă o astfel de alegere nu ar fi la fel de potrivită în cazul nostru.

\section{FLOARE (FIORE)}

Alta e floarea de grădină, / Și alta e floarea de câmp. Altro è il fiore di giardino, altro è il fiore di campo.

Si usa per distinguere gli uomini di città dai contadini, le persone colte dalle illiterate.

Câte flori sunt pe pământ, / Toate se duc în mormânt. Quanti flori ci sono sulla terra, / Tutti finiscono nella tomba. Il destino dell'uomo, nonostante tutto, è indirizzato verso la morte.

${ }^{21}$ Diadori 2018.:213-214. 
Numai cu o floare ghirlandă nu se face ${ }^{22}$.

Solo con un fiore ghirlanda non si fa.

Un singolo fatto non deve indurre a generalizzazioni affrettate.

[Un fiore non fa ghirlanda.]

Cu o floare numai vară nu se face.

Con un fiore solo l'estate non è fatta.

Variante del precente.

[Un fiore non fa primavera.]

A lua foc cu mâna altuia.

\section{FUOCO (FOC)}

Prendere del fuoco con la mano altrui.

$\mathrm{Ci}$ insegna ad affidare ad altri i lavori pericolosi.

Cu mână străină numai, foc să iei.

Solo con la mano estranea (di un altro) devi prendere del fuoco.

Interessante variante, dal costrutto particolare, del proverbio precedente.

Focul ce nu te supără, nici cum să-l sgândări ${ }^{23}$.

Il fuoco che non dà fastidio, non aizzarlo.

Inutile cercare motivo di discussione quando non è necessario.

Cu cât mai mult de foc te apropii, cu atât mai mult te și aprinzi.

Più ci si avvicina al fuoco, più ci si accende.

Riferito al sentimento amoroso: più ci si avvicina all'amore, più esso si sviluppa.

Tu îl trimiţi la foc, / Și el îţi aduce busuioc.

Tu lo mandi a prendere il fuoco / E lui ti porta il basilico.

Detto delle persone stolte e di chi fraintende le richieste altrui.

Focul în pădure din scânteie mică s-aprinde.

Il fuoco nel bosco da una piccola scintilla si accende.

Riferito ai futili motivi che inducono a litigare; basta poco per innescare un litigio.

\footnotetext{
${ }^{22}$ Ovvero: un singolo fatto, una singola prova non devono indurre a generalizzazioni affrettate. Si tratta di un proverbio molto diffuso e presente in tutte le lingue europee con molte varianti. Per Zanne, che riprende Golescu, il significato di questo proverbio è che non ci si può agghindare con poco; si tratta, a nostro avviso, di un'evidente incomprensione dell'allusione paremiologica.

${ }^{23}$ Grafia desueta del verbo "a zgândări”.
} 
Cine de foc trebuinţă are, în cenușă el găsește.

Chi ha bisogno del fuoco, lo trova nella cenere.

Si dice di chi conserva per sempre le cose, come la brace sotto la cenere.

Focul ce se socotește stins, de multe ori sub cenușă se găsește aprins.

Il fuoco che si considera spento, a volte sotto la cenere resta acceso.

Ossia, da dove non ti aspetti può arrivare il pericolo.

Până nu faci foc, fum nu iese ${ }^{24}$.

Fin quando non accendi il fuoco, fumo non esce.

Si usa per dire che finché non si commettono degli errori nessuno parlerà male di noi. Ci ricorda che dietro ogni calunnia vi è una base di verità.

[Non c'è mai fumo senza fuoco.]

Foc după foc, rău după rău.

Fuoco su fuoco, male su male.

Un male non viene mai da solo.

Focul când se-ncinge, / Anevoie se mai stinge.

Il fuoco quando divampa / Difficilmente si spegne.

Riferito a chi ha frequenti scatti d'ira.

Focul când s-aprinde p'in maracini uscaţi, arde și pe cei verzi.

Il fuoco quando si accende fra i rami secchi, brucia anche quelli verdi.

Si usa per ricordare che il male non ricade mai solo sui biasimevoli, ma anche sui virtuosi, così come le guerre coinvolgono sia i colpevoli sia gli innocenti.

Scapă-l din foc ca să te bage-n foc.

Difendilo dal fuoco che lui ti getta nel fuoco.

Dicesi delle persone irriconoscenti.

În urma focului mulţi dascăli se arată.

Finito (domato) il fuoco molti maestri si fanno avanti.

Per dire che bisogna offrire al momento opportuno i propri consigli non quando è troppo tardi.

A dat cu mânile-n foc. / E gros de ceafă, are de ros.

Ha frugato con le mani nel fuoco. / Grasso nel collo, ha da rosicchiare.

\footnotetext{
${ }^{24}$ Con una ricca serie di varianti: Nu e fum fără foc, Fum fără foc nu iese, Unde nu este foc nu este fum, ecc.
} 
Riferito a chi si è arricchito all'improvviso ed è diventato persona importante.

Când sunt zile și noroc, / Treci prin apă și prin foc.

Quando hai giorni e fortuna / Cammini nell'acqua e nel fuoco.

$\grave{E}$ un modo di dire che significa che quando si è forti fisicamente e spiritualmente niente fa paura.

Arde focu-n paie ude.

Arde il fuoco nella paglia bagnata.

Trattasi di un adagio dal doppio significato: si dice di un atteggiamento subdolo e pericoloso, ma anche di un uomo anziano che si innamora.

A se face foc și pară.

Farsi fuoco e fiamma.

Detto delle persone irascibili.

Fumul din ulei pe albină o scoate.

FUM (FUMO)

Il fumo dell'olio manda via (di casa) l'ape.

La povertà e i bisogni ti buttano fuori di casa.

Fumul se vede ziua, și noaptea arde focul.

Il fumo si vede di giorno e di notte arde il fuoco.

È un proverbio ricco di sapienza: le conseguenze delle azioni compiute nel passato (di notte) si vedono nel futuro (alla luce del giorno).

Ca să scapi de fum, de multe ori te-arunci în foc.

Per difenderti dal fumo, molte volte ti getti nel fuoco.

si cita il proverbio latino: de fumo ad flammam tendere.

Per sfuggire a un piccolo pericolo, si incorre in un pericolo maggiore.

Fum cam mare, dar frigarea cam mică.

Fumo piuttosto grande, ma spiedo piuttosto piccolo.

Attribuito a persone che vantano meriti che non hanno, che nonostante l'apparenza valgono poco.

[Tanto fumo e poco arrosto.]

\section{GÂRLĂ (RUSCELLO)}

Cine cade în gârlă nu se mai ferește de ploaie.

Chi cade nel torrente non ha più paura della pioggia.

Qui, riferito a cose che non possono più recare danno. 
$\mathrm{N}$-ai (a) ajuns la gârlă și ţi-ai (și-a) ridicat poalele.

Non sei (è) ancora arrivata al ruscello e ti sei (si è) già tirata su la sottana.

Si dice al riguardo di chi, prima del tempo, si preoccupiamo di qualsiasi cosa.

De or da alţii în gârlă, nici noi nu o să ne-nnecăm.

Se gli altri si buttano nel torrente, mica annegheremo anche noi.

Insegna che non si deve seguire il cattivo esempio degli altri.

Până treci gârla spui măgarului și: moșule!

Fino a che passi il rivo, all'asino lo chiami persino "zio"!

Ossia: finché scampi il pericolo, lusinghi chiunque ti possa essere d'aiuto.

Detto di chi è ruffiano e calcolatore.

Parcă-i prins de pe gârlă.

Sembra pescato nel torrente.

Si dice di persona trasandata e lurida.

\section{GRÂU (GRANO)}

Când se culcă grâul se scoală stăpînul.

Quando si corica il grano si alza (sveglia) il padrone.

Per comprenderne il significato bisogna ricorrere alla precisazione di Zanne: quando il grano si piega nel campo è segno che la spiga è piena e il padrone del campo si arricchirà.

Nu e grâu fără neghină $\breve{~}^{25}$.

Non c'è grano senza gettaione.

Nessuna cosa è perfetta, in ogni realtà convivono il bene e il male.

A fi cu grâul la gură.

Essere col grano alla bocca.

Zanne ne esplicita il significato: "adică cu sufletul în gură, gata să moară" (con l'anima alla bocca, sul punto di morire) ${ }^{26}$.

A căuta pe mama grâului.

Cercare la madre del grano.

Detto degli insaziabili, di coloro che non si accontentano di ciò che hanno.

\footnotetext{
${ }^{25}$ Neghina è una pianta che nasce tra il grano (gettaione). Il termine ricorre nell'espressione romena a alege neghina din grâu, grâul din neghină: separare il bene dal male.

${ }^{26}$ L'espressione può essere confrontata con il modo di dire a fi cu sufletul la gură: essere impaziente, avere fretta, essere ansioso.
} 


\section{GROAPĂ (FOSSO, FOSSA)}

Cine vrea să sară groapa, arunce-și mai întâi desagii peste ea.

Chi vuole saltare il fosso, prima ci butti sopra i suoi sacchi.

Prima di ogni impresa ci si deve sbarazzare delle difficoltà che la possono vanificare.

Cine sapă groapa altuia, cade singur într-însa ${ }^{27}$.

Chi scava la fossa altrui, ci finisce da solo dentro.

Nel tentativo di arrecare danno agli altri spesso facciamo male a noi stessi.

[Chi scava la fossa agli altri finisce per caderci.]

A săpa gropa cuiva.

Scavare la fossa a qualcuno.

Ovvero tendere una trappola.

A da în gropi.

Cadere (camminare) nei fossi.

Detto di persona stupida, di scarsissima intelligenza.

A da în gropi ziua mare, cu lumînarea.

Cadere nei fossi in pieno giorno, con la candela.

Come nel proverbio precedente, riferito a persona stupida, priva di senno.

Da în gropi de prost ce este.

Cadeva nei fossi per quanto era stupido.

È variante dei precedenti, ma qui il significato è espresso con l'aggettivo prost, mentre nei detti anteriori dev'essere decifrato.

A da din groapă în groapă.

Cadere da un fosso all'altro.

Si dice quando i mali si succedono, quando si passa da un male all'altro.

Era să-i cânte popa / Dar a sărit groapa.

Stava per cantagli il prete / Ma ha saltato la fossa.

$\mathrm{Si}$ fa riferimento al modo di dire a sări groapa: scampare alla morte.

\section{IARBĂ (ERBA)}

Iarba cea rea din rădăcină de-o vei tăia, ea iarbă tot va da ${ }^{28}$.

L'erba cattiva dalla radice se si taglierà, lei sempre erba crescerà.

\footnotetext{
${ }^{27}$ Numerosissime sono le varianti di questo proverbio veterotestamentario, segno che è molto comune e diffuso.

${ }^{28}$ Variante del più noto: Iarba rea nu piere (L'erba cattiva non muore mai).
} 
Per erbaccia si intende il male in generale, ma può significare anche persona cattiva.

[La mala erba non muore mai.]

Cu iarba cea uscată arde și cea verde.

Con l'erba secca brucia anche quella verde (tenera, fresca).

Oltre ai colpevoli, a volte pagano anche gli innocenti.

Unde nu e iarbă verde nu pasc oile.

Dove non c'è erba verde non pascolano le pecore.

L'uomo cerca sempre un luogo benigno, propizio al lavoro.

A avea iarba-fierului ${ }^{29}$.

Avere il vincetossico.

Detto di persona che riesce in tutte le sue imprese, ma anche riferito a un ladro molto abile.

Pe ce iarbă ai călcat?

Quale erba hai calpestato?

Espressione che si usa quando ci si rivolge a si arrabbia all'improvviso e senza motivo.

Când mi-o crește iarbă-n barbă.

Quando mi crescerà erba nella barba.

Detto di cose che non succederanno mai.

Lac să fie, broaște s-adună.

$$
\text { LAC (LAGO) }
$$

Importante è che ci sia il lago, le rane (poi) arrivano.

Si dice di ciò che si trova con difficoltà.

A sărit din lac în puţ.

È saltato dal lago nel pozzo.

Riferito a chi, per sfuggire a un pericolo si trova di fronte a un pericolo più grande.

[Cadere dalla padella alla brace.]

Mă duc să mă-nnec, / Unde-o fi lacul mai sec.

Vado ad annegare / Dove il lago sarà più secco.

Modo scherzoso di rivolgersi a chi si finge disperato.

${ }^{29}$ Nota anche come iarba fiarelor, iarba tâlharilor. 
Lemnul strîmb, focul îl îndreptează.

\section{LEMN (LEGNO)}

Il legno storto si raddrizza col fuoco.

Alle persone cattive serve una bella punizione.

Dintr-un lemn faci și cruce și lopată.

Con un pezzo di legno si fa sia una croce sia una pala.

Riferito a genitore che può crescere figli sia buoni sia cattivi.

Orice lemn își are viermele său.

Ogni legno ha il suo tarlo.

Ogni persona ha i propri dispiaceri.

Pe unde tăiam lemne, acum adunăm surcele.

Laddove si tagliava la legna, oggi si raccolgono legnetti.

Le ricchezze del passato contrastano con la povertà del presente.

Pe lângă lemnul uscat arde și cel verde.

Insieme alla legna secca arde anche quella fresca.

Oltre ai colpevoli, patiscono anche gli innocenti.

Lemnul care se îndoiește e mai bun decât cel care se rupe.

Il legno che si piega è meglio di quello che si spezza.

Occorre adattarsi alle circostanze ed essere persone malleabili.

Cu un lemn foc nu se face.

Con un legno non si accende il fuoco.

Riferito alle persone in stato di povertà.

\section{MAL (RIVA, SPONDA)}

Ca să ieși la mal cu toate, îți trebuie limbă de aur ori pungă de aur.

Per portare a riva (a buon fine) ogni cosa, occorre avere una lingua d'oro oppure una borsa d'oro.

Per riuscire nella vita bisognerebbe avere il dono della parola oppure essere molto ricchi.

A se bate ca apa de maluri.

Agitarsi (dimenarsi) come l'acqua che batte contro la riva.

Detto di persone che soffrono in solitudine, senza ricevere l'aiuto di nessuno.

A se înneca tocmai la mal.

Affogare (quando si è arrivati) a riva. 
Non riuscire a portare a buon fine un'impresa.

\section{MARE (MARE)}

Marea-i plină de talazuri, / Și lumea cu feluri de necazuri.

Il mare è pieno di onde gigantesche / $\mathrm{E}$ il mondo di diverse sofferenze.

Sta a significare che le disgrazie e le sfortune riguardano tutti.

Când ești în luciul mării și tună, /Anevoie o să scapi de furtună.

Quando sei in mezzo al mare e tuona / Difficile evitare la tempesta.

Nella vita esistono indizi precisi che predicono le sofferenze future.

Numai cu un găinaţ de cioară marea nu se spurcă.

Solo con la cacca di una cornacchia il mare non si sporca.

Un unico errore non può macchiare la dignità di un'intera vita.

A cerca (încerca) marea cu degetul.

Tastare (controllare) il mare con un dito.

Aspirare a cose irraggiungibili.

Făgăduiește marea cu sarea.

Promette il mare con il sale.

Promettere cose impossibili.

Peste nouă mări și nouă ţări.

Oltre (sopra) nove mari e nove paesi.

La locuzione, diffusa nelle fiabe romene, indica un luogo molto lontano.

\section{Bibliografie:}

Braga 2008 = Victoria Braga, „Prefaţă”, în Elena Grosu, Victoria Braga, Dicționar de proverbe și zicători, Chișinău, Epigraf.

Carlateanu et alii 2007 = Tatiana Cartaleanu, Olga Cosovan, Elena Cartaleanu „Proverbul privit ca text”, în Idem, Dicționar de proverbe comentate, Chișinău, Știința.

Constantinescu 2003 = Nicolae Constantinescu, „La o reeditare”, în Iuliu A. Zanne, Proverbele Românilor din România, Basarabia, Bucovina, Ungaria, Istria şi Macedonia (I), Bucureşti, Scara, 5-14.

Datcu 2004 = Iordan Datcu, $O$ restituire necesară, în „România literară”, 39, p. 7.

Diadori 2018 = Pierangela Diadori, Tradurre: una prospettiva interculturale, Roma, Carocci. 
Fanella, Zuliani 2014 = Celestina Fanella, Alessandro Zuliani, I proverbi romeni nella raccolta di Iuliu A. Zanne, în Federica Cugno et alii (eds.), Studi linguistici in onore di Lorenzo Massobrio, Torino, Istituto dell'Atlante Linguistico, p. 389-416.

Franceschi $2004=$ Temistocle Franceschi, La formula proverbiale, în Valter Boggione, Lorenzo Massobrio, Dizionario dei proverbi. Torino, UTET, p. IX-XXII.

Guazzotti, Odderra 2006 = Paola Guazzotti, Maria Federica Odderra, Il grande dizionario dei proverbi italiani, Bologna, Zanichelli.

Imbriani 2004 = Eugenio Imbriani, La traduzione nella prospettiva antropologica, în G. Gallo, P. Scoletta, La traduzione. Un panorama interdisciplinare. Nardò, BESA, p. 59-66.

Lapucci 2006 = Carlo Lapucci, Dizionario dei proverbi italiani, Firenze, Le Monnier, p. VII-XLII.

Librici 2016 = Ivana Librici, Fraseologia contrastiva e traduzione in "Contos da Montanha” di Miguel Torga, în Elena Dal Maso, Carmen Navarro (eds.), Gutta cavat lapidem. Indagini fraseologiche e paremiologiche, Mantova, Universitas Studiorum, p. 457-473.

Navarro Salazar 1999 = María Teresa Navarro Salazar, Problemi di traduzione paremiologica: il caso di I Malavoglia, în Salvatore C. Trovato (ed.), Proverbi locuzioni modi di dire nel dominio linguistico italiano, Roma, Il Calamo, p. 157-175.

Nikolaeva 2011 = Julija Nikolaeva, Problemi di equivalenza nel vocabolario paremiologico russo-italiano, în Temistocle Franceschi (ed.), Ragionamenti intorno al proverbio. Atti del II Congresso internazionale dell'Atlante Paremiologico Italiano, Alessandria, Edizioni dell’Orso, p. 195-205.

Negreanu 1983 = Constantin Negreanu, Structura proverbelor românești, București, Editura Științifică și Enciclopedică.

Osimo 2004 = Bruno Osimo, Manuale del traduttore, Milano, Hoepli.

Tejera Rolando 2016 = María Josefina Tejera Rolando, Acercamiento al anális estructural de los provierbos, în Elena Dal Maso, Carmen Navarro (eds.), Gutta cavat lapidem. Indagini fraseologiche e paremiologiche, Mantova, Universitas Studiorum, p. 255-268.

Teodorescu 1877 = Gheorghe D. Teodorescu, Cercetări asupra proverbelor române, București, Nouă Tipografie a Laboratorilor Români.

Tosi 2017 = Renzo Tosi, Introduzione, în Renzo Tosi (ed.), Dizionario delle sentenze latine e greche, Milano, BUR, p. I-XXVIII.

Trovato $2011=$ Salvatore C. Trovato, Il proverbio come oggetto lessicografico, în Temistocle Franceschi (ed.), Ragionamenti intorno al proverbio. Atti del II Congresso internazionale dell'Atlante Paremiologico Italiano. Alessandria, Edizioni dell'Orso, p. 83-92. 
Wozniak $2010=$ Audrey Wozniak, Peut-on traduire un proverbe?, în „Ela. Études de linguistique appliquée" 1, 157, p. 35-48.

Zanne 2003 = Iuliu A. Zanne, Proverbele Românilor din România , Basarabia, Bucovina, Ungaria, Istria şi Macedonia (I), Bucureşti, Scara.

Zuliani 2016 = Alessandro Zuliani, Concordanze paremiologiche romeno-friulane, în Alessandra Ferraro (ed.), Dal Friuli alle Americhe. Studi di amici e allievi udinesi per Silvana Serafin, Udine, Forum, p. 165-172.

Zuliani 2017 = Alessandro Zuliani, Non solo proverbi: modi di dire, locuzioni, credenze popolari raccontati da Iuliu A. Zanne, în „Bollettino dell'Atlante Linguistico Italiano" III, 41, p. 19-54. 